\title{
E-cadherin and NM23HI as metastasis predictors for various degrees of histological malignancy in invasive ductal carcinoma
}

\author{
Primariadewi Rustamadji, ${ }^{l}$ Ahmad Tjarta, ${ }^{l}$ Santoso Cornainm, ${ }^{l}$ Muchlis Ramli, ${ }^{2}$ Esti Soetrisno ${ }^{I}$ \\ 1 Department of Anatomic Pathology, Faculty of Medicine Universitas Indonesia/Cipto Mangunkusumo Hospital \\ 2 Department of Oncology Surgery, Faculty of Medicine Universitas Indonesia/Cipto Mangunkusumo Hospital
}

\begin{abstract}
Abstrak
Latar belakang: Penelitian ini bertujuan untuk menganalisis apakah ekspresi protein E-cadherin dan NM23H1 dapat digunakan sebagai prediktor invasi dan metastasis karsinoma duktal payudara pada berbagai derajat keganasan .

Metodologi: Subyek penelitian adalah 97 wanita yang telah didiagnosis menderita karsinoma payudara duktal invasif derajat 1,2, dan 3 yang spesimen biopsinya dikirim ke laboratorium histopatologi rumah sakit di Jakarta dan Bandung antara tahun 2000-2006. Pemeriksaan histopatologis dengan pulasan hematoksilin eosin terhadap blok parafin yang berasal dari tumor primer maupun sekunder dilakukan untuk penentuan derajat keganasan dan status metastasis. Selanjutnya dilakukan pemeriksaan imunohistokimia terhadap ekspresi E-cadherin, NM23H1 dan sitokeratin di jaringan tersebut serta dilakukan skoring berdasarkan jumlah sel terwarnai dan intensitas pewarnaan. Analisis dilakukan untuk mengetahui hubungan ekspresi E-cadherin dan NM23H1 dengan metastasis dan derajat keganasan histologik.

Hasil: Subyek berusia antara 29-75 tahun dengan rerata 48,19 tahun dan terbanyak berusia 40-45 tahun, dengan derajat keganasan 1 sebanyak 18,56\%, derajat 2 sebanyak 45,36\% dan derajat 3 sebanyak 36,1\%. Terdapat hubungan bermakna antara ekspresi E-cadherin dan NM23H1 pada tumor primer dengan kemungkinan E-cadherin menghambat invasi dan metastasis sebesar 14 kali sedangkan NM23H1 sebanyak 11 kali dibandingkan subyek yang tidak mengekspresikan E-cadherin dan atau NM23H1. Kurva ROC menunjukkan ekspresi E-cadherin $(r=0,755)$ dan NM23H1 $(r=0,816)$ berkorelasi kuat, sensitif dan spesifik sebagai petanda metastasis akan tetapi tidak berhubungan dengan derajat keganasan histologik
\end{abstract}

Kesimpulan: Ekspresi E-cadherin dan NM23H1 dapat digunakan sebagai petanda invasi dan metastasis, tetapi tidak dapat digunakan sebagai petanda derajat keganasan histologik karsinoma duktal invasif payudara. (Med J Indones 2011; 20:263-70)

\begin{abstract}
Background: This study aims to analyze whether the expressions of E-cadherin and NM23HI can be used as predictors of ductal carcinoma metastasis in various degrees of malignancies.

Methods: Paraffin blocks were obtained from 97 patients with invasive breast ductal carcinoma with malignancy grade 1,2 and 3 who came to several hospitals in Jakarta and Bandung from 2000 to 2006. Histopathological examinations of hematoxylin eosin slides of primary and secondary tumors were done to diagnose the degree of histological malignancy and metastasis status. Further, immunohistochemistry staining of E-cadherin, NM23HI and cytokeratin were done followed by scoring according to the number of positive cells and staining intensity. The associations of E-cadherin and NM23H1 expression with the presence of metastasis and grade of histological malignancy were analyzed.

Results: Subjects were 29-75 years old (mean: 48.19 years), with most subjects aged 40-45 years old, with malignancy grade 1,2 and 3 of $18.56 \%, 45.36 \%$ and $36.1 \%$ respectively. There was a significant association between E-cadherin and NM23HI expression in primary tumors. The possibility of invasion and metastasis inhibition by positive E-cadherin and NM23HI was 14 and 11 times respectively compared to those with negative E-cadherin and/ or NM23HI expression. The ROC curve showed that E-cadherin $(\mathrm{r}=0.755)$ and $\mathrm{NM} 23 \mathrm{HI}(\mathrm{r}=0.827)$ expressions were strongly associated, sensitive and specific as metastasis markers. However, E-cadherin and NM23HI expression did not show significant association with histological degree of invasive ductal carcinoma.
\end{abstract}

Conclusion: E-cadherin and NM23HI expressions can be used as invasion and metastasis markers, but cannot be used as markers for the degree of histological malignancy of invasive ductal carcinoma. (Med J Indones 2011; 20:263-70)

Keywords: Breast cancer, E-cadherin, NM23HI

The incidence of breast cancer occupies the first position of malignancies in the world ${ }^{1}$ and second in Indonesia next to cervical cancer. ${ }^{2}$ Many cancer patients visit their doctors at an advanced stage that make the treatment and therapy difficult. The worst of all is, in Indonesia, most of cancer patients are still young and productive. ${ }^{3}$

Based on the records in Dr. Cipto Mangunkusumo hospital, invasive ductal carcinoma is the subtype of breast carcinoma with the highest incidence, i.e. 85 to $90 \%$ (Mangunkusumo R, personal communication). Early detection of invasive ductal carcinoma in its early stage can provide maximum and affordable treatments to the patients.

Invasion and metastasis determine the types of therapy. Patients without invasion and metastasis may need only primary tumor removal without axillary's lymph 
node removal, radiation and chemotherapy. Patients with metastasis potency need further treatments including axillary's lymph node removal, radiation and chemotherapy. Markers to predict the occurrence of metastasis may alert doctors and patients from the emergence of loco regional metastasis, so that doctors can give optimal treatment, preserve patients' productivity and better ensure patients' recovery. ${ }^{4}$

Previous studies concluded that predictors of metastasis, until now, is not yet clear, while therapy and prognostic factors of patients are very dependent on the prediction of metastasis. ${ }^{4}$ Therefore, it is necessary to develop alternatives that can predict and estimate the prognosis of patients in early stages of breast ductal carcinoma. These alternatives should be more accurate, affordable, and available. Combinations of clinical, histopathological and immunohistochemical examinations are currently being developed rapidly. These alternatives are expected to detect or predict the potential of metastasis to the lymph nodes or distant metastases. Therefore, accurate invasion and metastasis markers of invasive ductal carcinoma to detect in early stage are highly required, and this study aims to analyze whether the expressions of E-cadherin and NM23HI can be used as predictors of ductal carcinoma metastasis in various degrees of histological malignancies.

\section{METHODS}

This is a cross sectional study conducted in the Department of Anatomic Pathology, Faculty of Medicine, Universitas Indonesia, Cipto Mangunkusumo Hospital, from November $1^{\text {st }}$ to December $31^{\text {st }}, 2006$.

\section{Data collection}

Data were retrieved from the archives of the Department of Anatomic Pathology, Faculty of Medicine Universitas Indonesia/Cipto Mangunkusumo Hospital, Jakarta, Kramat 128 Hospital Jakarta, Jakarta Breast Centers, Public Hospitals Hasan Sadikin, Bandung, Jakarta Islamic Hospital and the Darmanugraha Hospital Rawamangun, Jakarta. The data retrieved were: the hospital origin of specimen, age, sub-type of tumor, tumor grade, and lymph node metastasis.

The data recorded from the immunohistochemical staining results were the positivity and expression streghth of E-cadherin and NM23H1 in primary tumors, and metastases in lymph nodes in invasive ductal breast carcinoma.

\section{Samples}

The samples were HE slides and paraffin blocks of breast mastectomy cases from several hospitals in Jakarta and
Bandung from 2000 to 2006 that met the inclusion criteria, i.e. breast carcinoma that had been histopathologically diagnosed as invasive ductal breast carcinoma with low grade of malignancy (grade I) with and without metastases in lymph nodes, grade II with and without metastases in lymph nodes, and high grade (grade III), when good or reliable paraffin blocks are available. Exclusion criteria are unreliable paraffin blocks (e.g. broken/damaged paraffin blocks, paraffin blocks whose tumor mass is cut or eaten by animals, etc).

\section{Calculation of sample size}

The sample size was calculated using P1 and P2 for E-Cadherin and NM23H1, with alpha $=5 \%$, confidence interval $=95 \%$, and power $=80 \%{ }^{5,6}$ The sample sizes that were calculated were 11 and 24 , respectively. The samples were selected using consecutive sampling. Combination of NM23H1 plus E-cadherin examinations was expected to make the prediction to be more significant. It was expected that the accuracy of the prediction would reach ninety percent.

\section{Slide preparation and immunohistochemical staining $^{4,7}$}

Theparaffinblockswerecutandimmunohistochemically stained; blocks of primary tumors and their metastases in lymph nodes were stained with E-cadherin and $\mathrm{NM} 23 \mathrm{H} 1$, while blocks of lymph nodes without metastasis were stained with cytokeratin to make sure that there was no metastasis in lymph nodes.

Immunohistochemical staining used the Streptavidine Biotin complex labeling method. The primary antibodies against E-cadherin, NM23H1 and Cytokeratin were mouse monoclonal antibodies, i.e. mouse monoclonal anti CDH1 antibody, Ig I:200 (Novocastra), NM23H1 antibody, Ig I:100 (Novocastra) and for cytoceratin was anti A1/E3 antibody, Ig I:100 (Daco). Every staining included negative controls using the same breast carcinoma tissue; each running consisted of 8 10 cases with a positive control of breast carcinoma insitu, and staining results were analyzed using standard assessment techniques.

Assessment and reading of immunohistochemical stainings were carried out by two anatomic pathologists and researchers who are experienced in reading histopathological slides. Assessment of E-cadherin expression was performed in 500 tumor cells from 5 different large fields $(400 \mathrm{x})$ that were chosen randomly. Each region was represented by 100 tumor cells. E-cadherin positivity was represented by brown staining of the tumor cell membrane or cytoplasm. Degree of positivity of E-cadherin was assessed by a scoring system that used the percentage of positive value 
(the value of color intensity by Nichols). ${ }^{7}$ Assessment of $\mathrm{NM} 23 \mathrm{H} 1$ expression was performed in the same way with E-cadherin, but NM23H1 positivity was represented by brown staining in cytoplasm of tumor cells, and the positivity of cytokeratin was represented as brown staining in the intra-tumor cell cytoplasm. The degree of positivity of cytokeratin was assessed in the same manner as above. ${ }^{7}$ The assessment of all expressions was done on the entire area on small field (magnification $100 \mathrm{x}$ ) and large field (magnification $400 \mathrm{x})$.

\section{Data analysis}

The data were entered into a main table, and data analyses were done using SPSS version 13 and Med Calc version 9.6.4.0 software. Chi square test were used to calculate the Odds ratio (OR) and 95\% confidence interval $(95 \% \mathrm{CI})$ for E-Cadherin and NM23H1 positivity as well as expression strength on the occurrence of metastatic tumors compared to non metastatic tumors. In addition the OR and $95 \%$ CI for tumor E-Cadherin and NM23H1 positive expression on the occurrence of lymph node positivity compared to negative expression were calculated. Further, diagnosis test to get the sensitivity and specificity value from the ROC curve using E-Cadherin and NM23H1 positivity was done. ${ }^{6,8,9}$ Presentation of data was done in tables, pictures and graphs.

\section{RESULTS}

Forty-eight cases of non metastatic ductal breast carcinoma and forty-nine cases of metastatic ductal breast carcinoma were included in the study.

The comparison of the expressions of E-cadherin in nonmetastasic to those in metastatic primary tumor in patients with invasive ductal breast carcinoma revealed that the chance of positive E-cadherin to prevent metastasis is 13.6 times of that with negative E-cadherin $(95 \% \mathrm{CI}=$ $1.68 ; 110, \mathrm{p}<0.01)$.
Table 1 shows that the chance of weak and moderate positive E-cadherin expression to prevent metastasis was nine and thirty times of that with negative E-cadherin expression, respectively.

Further, the chance of positive expression of NM23H1 to prevent metastasis is 11.3 times of negative expression of $\mathrm{NM} 23 \mathrm{H} 1,95 \% \mathrm{CI}=4.29 ; 30, \mathrm{p}<0.001$.

Comparison of NM23H1 expression grade shows that the chance of weak positive NM23H1 expression to prevent metastasis is eight times as much as that of negative expression $(95 \% \mathrm{CI}=2.94 ; 21.4, \mathrm{p}<0.0001)$. The chance of moderate positive NM23H1 expression to prevent metastasis is 50 times as much as that of negative expression $(95 \% \mathrm{CI}=5.82 ; 439 ; \mathrm{p}<0.0001)$.

Strong positive E-cadherin and NM23H1 expression cannot be valued due to the minimum number of samples and the presence of zero in both E-cadherin and NM23H1 expressions. Expression gradation comparison shows an increase in Odds ratio from weak to moderate positive that is eight to fifty times (Table 2).

The number of E-cadherin positive expression in lymph nodes is high in E-cadherin positive primary tumors with a 0.111 -time decrease in positive expression in Lymph nodes compared to E-cadherin negative primary tumors $(95 \% \mathrm{CI}=0.0025 ; 0.802, \mathrm{p}<0.001)$.

Ahigh number of positive NM23H1 expressions occured in lymph nodes of $\mathrm{NM} 23 \mathrm{H} 1$ negative primary tumors with a 0.034 -time decrease in positive expression in lymph nodes compared to NM23H1 positive primary tumors $(95 \% \mathrm{CI}=0.00079 ; 0.208, \mathrm{p}<0.001)$. The disagreement is due to a " 0 " (zero) in one cell.

Table 3 shows positive and negative results of E-cadherin and NM23H1 expressions in non metastasized compared to metastasized primary tumors. In both positive and combination of positive and negative expression the chance of invasion and metastasis prevention is 29 and 9 times of that in both negative expressions.

Table 1. Chi square test of gradation of E-cadherin expressions in non-metastasic compared to those in metastatic primary tumor

\begin{tabular}{lllllll}
\hline \multirow{2}{*}{ E-cadherin expressions } & \multicolumn{3}{c}{ Primary tumor } & \multirow{2}{*}{ OR } & \multirow{2}{*}{ CI } \\
\cline { 2 - 5 } & Non Metastatic & $\%$ & Metastatic & $\%$ & & $1.19 ; 217$ \\
Strong positive & 2 & $(4.1 \%)$ & 0 & $(0 \%)$ & 18 & $3.23 ; 276$ \\
Moderate positive & 19 & $(39.6 \%)$ & 7 & $(14.3 \%)$ & 29.9 & $1.12 ; 6.3$ \\
Weak Positive & 26 & $(54.2 \%)$ & 31 & $(63.3 \%)$ & 9.23 & \\
Negative & 1 & $(2.1 \%)$ & 11 & $(22.4 \%)$ & 1 (Ref) & \\
Total & 48 & $(100 \%)$ & 49 & $(100 \%)$ & & \\
\hline
\end{tabular}

$\mathrm{x}^{2}=14.14682 \quad \mathrm{p}<0.0001$ 
Table 2. Chi square test results of gradation of NM23H1 expressions in non metastatic primary tumor compared metastatic primary tumors

\begin{tabular}{|c|c|c|c|c|c|c|}
\hline \multirow{2}{*}{ NM23H1 Expression } & \multicolumn{4}{|c|}{ Primary tumor } & \multirow{2}{*}{ OR } & \multirow{2}{*}{$95 \% \mathrm{CI}$} \\
\hline & Non Metastatic & $\%$ & Metastatic & $\%$ & & \\
\hline Strong positive & 0 & $(0 \%)$ & 0 & $(0 \%)$ & 3.89 & $0.221 ; 68.4$ \\
\hline Moderate positive & 12 & $(25 \%)$ & 0 & $(0 \%)$ & 50.6 & $5.82 ; 439$ \\
\hline Weak positive & 28 & $(58.3 \%)$ & 15 & $(30.6)$ & 7.93 & $2.94 ; 21.4$ \\
\hline Negative & 8 & $(16.7 \%)$ & 34 & $(69.4)$ & 1 & (Ref) \\
\hline Total & 48 & $(100 \%)$ & 49 & $(100 \%)$ & & \\
\hline
\end{tabular}

$\mathrm{x}^{2}=26.74 \quad \mathrm{p}<0.0001$

Table 3. Chi square test of $\mathrm{E}+/ \mathrm{N}+$; E+/N-, E-/N+, E-/N- expressions in non metastatic and metastatic primary tumor

\begin{tabular}{|c|c|c|c|c|c|c|c|c|c|}
\hline \multirow[t]{2}{*}{ E/N expressions } & \multicolumn{4}{|c|}{ Primary Tumors } & \multirow{2}{*}{ Total } & \multirow{2}{*}{$\%$} & \multirow{2}{*}{ OR } & \multirow{2}{*}{$95 \% \mathrm{CI}$} & \multirow{2}{*}{$\mathrm{p}$} \\
\hline & Non-metastatic & $\%$ & Metastatic & $\%$ & & & & & \\
\hline $\mathrm{E}+/ \mathrm{N}+$ & 40 & $(72.7 \%)$ & 15 & $(27.3 \%)$ & 55 & $(100 \%)$ & 29.333 & $3.481 ; 247.179$ & 0.002 \\
\hline $\mathrm{E}+/ \mathrm{N}-$ & 7 & $(23.3 \%)$ & 23 & $(76.7 \%)$ & 30 & $(100 \%)$ & 8.762 & $3.117 ; 24.626$ & 0.000 \\
\hline E-/N- & 1 & $(8.3 \%)$ & 11 & $(91.7 \%)$ & 12 & $(100 \%)$ & REFERENCE & & \\
\hline Total & 48 & $(100 \%)$ & 49 & $(100 \%)$ & 97 & $(100 \%)$ & & & \\
\hline
\end{tabular}

E $+=$ Positive e-cadherin, E - = Negative e-cadherin, $\mathrm{N}+=$ Positive NM23H1, N - = Negative NM23H1

ROC curve is to illustrate the sensitivity and specificity of each marker - E-cadherin and NM23H1 - in the prediction of metastasis and histological grade of malignancy. The ROC curve can predict the best marker. The sensitivity and the specificity of E-cadherin expression to predict the occurrence of metastasis was $59.2 \%$ and $87.5 \%$, respectively, with a cutoff point of $\leq$ 40 , and an area under the curve of 0.755 .

The sensitivity and the specificity of NM23H1 expression to predict the occurrence of metastasis is $69.4 \%$ and $83.3 \%$ respectively, with a cutoff point of $\leq 0$, and an area under the curve of 0.827 .

The two curves show that as a metastasis marker, E-cadherin expression is specific, while NM23H1 expression is both specific and sensitive. Comparison of the curve of E-cadherin and NM23H1 expressions in metastasis prediction shows an area of difference of 0.048 . The ability of E-cadherin and NM23H1 to predict metastasis does not differ significantly when the difference limit is 0.05 (Figure 1).

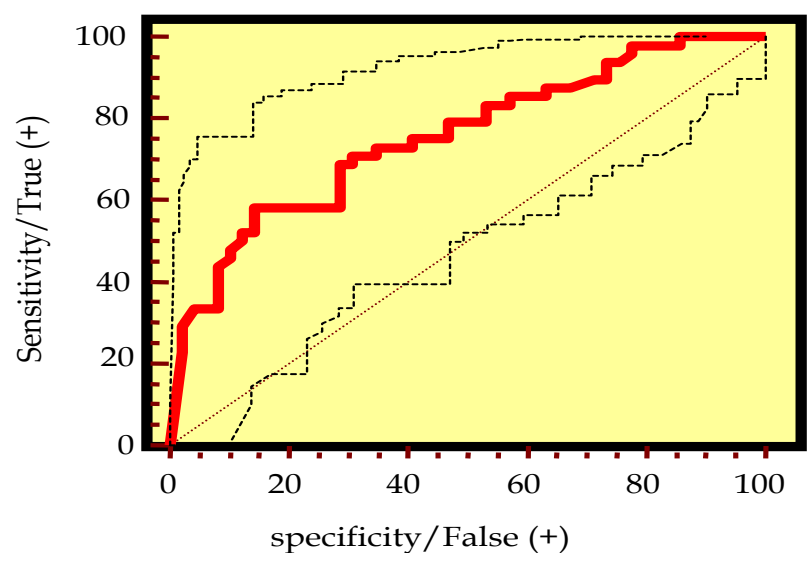

Figure 1. The curve of relationship between E-Cadherin expressions and metastasis

\section{The Results of Immunohistochemistry Staining}

The results of immunohistochemistry staining of E-Cadherin and NM23H1 can be seen in Figure 2-3.

Two pathologists' calculations of immunohistochemical readings gave likelihood ratios of 11.2 and 4.31. E-cadherin prediction of the occurrence of metastasis is eleven, while $\mathrm{NM} 23 \mathrm{H} 1$ prediction is four. In lymph nodes, likelihood calculation is not performed because the purpose is different. Metastasis prediction before and after immunohistochemistry with a priori compared to a posteriori probability according to Veneis method showed an increase of $49.4 \%$ for E-cadherin and $49.27 \%$ for $\mathrm{NM} 23 \mathrm{H} 1 .{ }^{9}$

Figure 4a shows that all primary tumors with moderate positive E-cadherin expressions have moderate positive expression in lymph nodes. Some primary tumors with weak positive E-cadherin expressions (approximately twenty-five percent) have moderate positive E-cadherin expressions in lymph nodes and the rest (approximately seventy-five percent) have weak positive E-cadherin expressions in lymph nodes. In primary tumors with negative E-cadherin expressions, there are weak positive, strong positive and also negative E-cadherin expressions in the lymph nodes.

Figure $4 \mathrm{~b}$ shows that weakpositiveNM23H1 expressions in primary tumors have positive NM23H1 expressions in lymph nodes, which is roughly one-third that have moderate positive, while the rest (approximately twothirds) have weak positive expressions in the lymph nodes. Negative NM23H1 expressions in primary tumors have negative, weak positive, and strong positive NM23H1 expressions. 
a

\section{$250 \mu \mathrm{m}$}

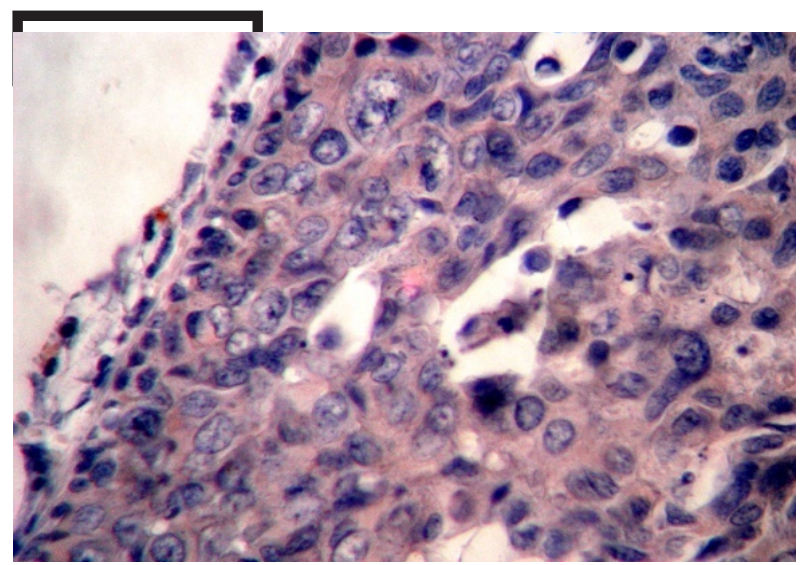

b

\section{$250 \mu \mathrm{m}$}

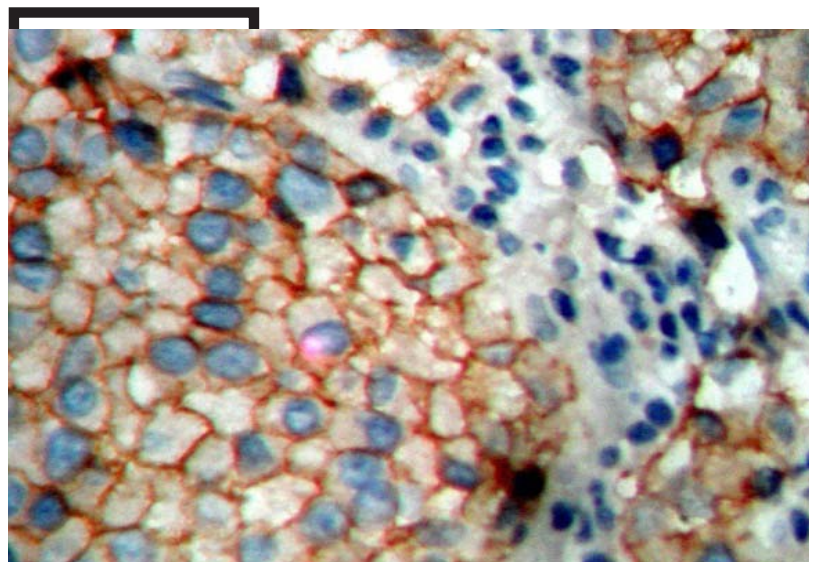

Figure 2. Negative and strong positive E-cadherin expression in invasive ductal breast carcinoma Magnification 400x $a=$ negative expression, $b=$ strong positive expression

a

\section{$1 \mathrm{~mm}$}

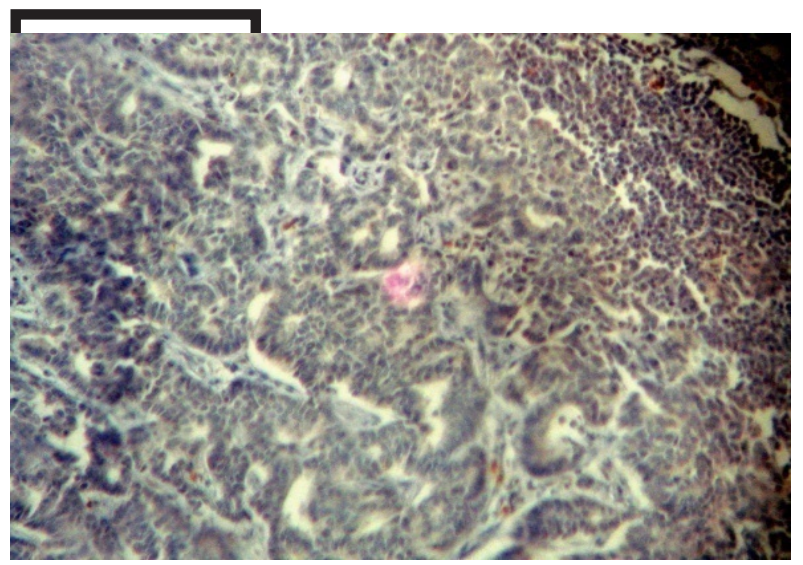

b

\section{$1 \mathrm{~mm}$}

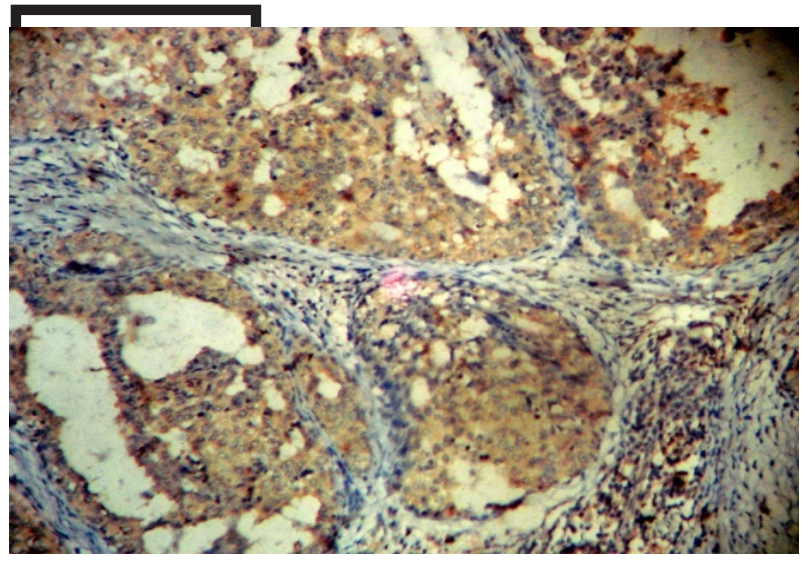

Figure 3. Negative and moderate positive NM23H1 expression in invasive ductal breast carcinoma. Magnification 100x $a=$ negative expression, $b=$ moderate positive expression
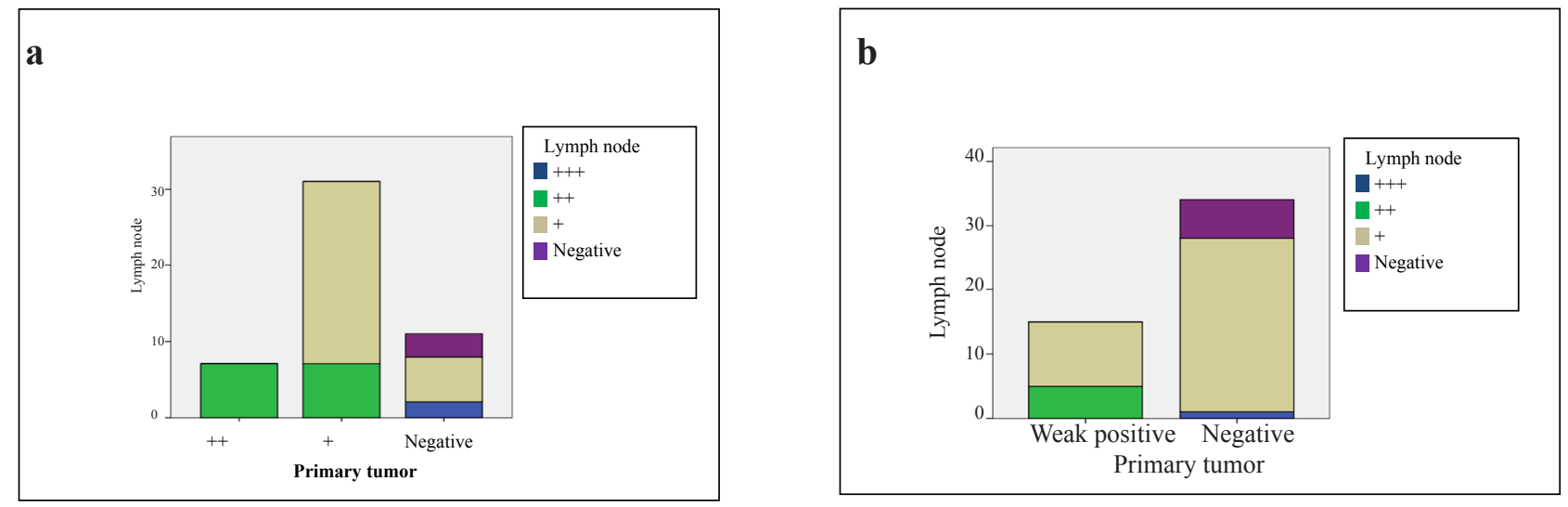

Figure 4. E-cadherin, and NM23HI expression in primary tumor and its metastasis in lymph nodes $a=$ E-cadherin, $b=N M 23 H I$ 


\section{DISCUSION}

Among carcinoma sub types, such as lobular, papillary and medullary, invasive ductal breast carcinoma incidence has the highest rate. As a top referral hospital, the breast carcinoma patients who come to Cipto Mangunkusumo central national hospital may represent breast carcinoma patients in Indonesia. During the search of the cases, various problems appeared so that the expected minimum samples required were not fulfilled. Therefore, some samples were obtained from some other hospitals in Jakarta and Bandung, as mentioned in the methods, and it is expected that the samples will represent breast cancer patients in Indonesia.

Reliable paraffin blocks that met the inclusion criteria from ninety-seven cases were obtained. The selection and the reading of immunohistochemical slides were carried out by two experienced anatomic pathologists so that the internal validity is expected to be good.

The cases used are mastectomy cases of invasive ductal breast carcinoma with grade malignancy one, two and three. In situ ductal breast carcinoma was not included due to the scarcity of cases diagnosed. In situ ductal carcinoma gives strong positive expressions, especially E-cadherin expression, because the cell-cell adhesion in in situ ductal carcinoma is very strong, and micro-invasion has not occurred yet. Therefore, in this study, in situ ductal carcinoma was used as positive controls of E-cadherin and NM23H1 immunohistochemistry staining.

It is known that metastasis occurs not only to axillary lymph nodes, as metastasis may occur in internal mammary lymph node, areas of clavicula, or other organs. However, all invasive ductal carcinoma cases in this study came from mastectomy with metastasis only to axillary lymph node, as far metastasis is contra indication to mastectomy.

Table 2 shows an increase in Odds Ratio from weak positive and moderate positive to eight and fifty times compared to that of negative expression. These results agree with one of NM23H1 working mechanisms, which is as metastasis suppressor that reduces cell motility and lowers cell differentiation to malignancy that may reduce or prevent the occurrence of invasion and metastasis. ${ }^{10}$

Various studies have tried to relate the decrease in E-cadherin expression to tumor growth and metastasis in breast and in other carcinomas. E-cadherin is a transmembrane glycoprotein that mediates intercellular adhesion that depends on calcium, and is specifically involved in epithelial cell-cell adhesion. E-cadherin gene is located at chromosome 16q22.1, and works as a very important morphogenetic regulator. In carcinoma, decrease in E-cadherin expression is one of the changes that lead to invasive phenotype characters. Moreover, data from several researchers support E-cadherin's role as tumor suppressor gene and as suppressor of invasion and metastasis. ${ }^{11}$

Decreased E-cadherin expression is related to high invasion and advance stage of prostate, colon, colorectal, and breast carcinomas. Especially in breast carcinoma, decreased E-cadherin expression is related to negative estrogen receptor and high metastasis. ${ }^{11}$ However, our study showed that positive expression is a good marker for invasion and metastasis in lymph nodes.

Metastasis is a serious problem for doctors in treating breast carcinoma. The problems will be more complicated due to different therapy protocols that should be administered to breast carcinoma patients with or without metastasis. Despite the so many studies in this field, metastasis processes, either locoregionally to lymph node or systematically to far organs, are still confusing.

Among so many identified groups of gene suppressors, cadherin should get specific attention. ${ }^{12}$ It agrees with the results of the studies stating that loss or disturbance of E-cadherin expression can increase motility, local invasion, and metastasis. ${ }^{13-16}$ Graff et al. (cited by Madhavan, et al. 2001) found that decreased E-cadherin expression is caused by $\mathrm{CpG}$ island hypermethylation of E-cadherin gene promoter region. ${ }^{12}$

Table 2 shows an increase in Odds ratio of NM23H1 expression from weak positive to moderate positive. This result agrees with one of NM23H1 roles, which is as a metastasis suppressor that reduces cell motility, lowers cell differentiation, thus reducing or preventing invasion and metastasis. Decreased NM23H1 will activate RAF-MOS. Activated RAF-MOS will phosphorilize MEK 1-2, and activated MEK 1-2 will activate ERK, which promotes metastasis. ${ }^{17}$

E-cadherin and NM23H1 expression in most of the lymph nodes in our study can be explained by the results of Kowalczyk et al.1994, who found decreased E-cadherin expression in invasive ductal carcinoma that caused the carcinoma to grow and metastasized to both lymph nodes and far sites. Cancer cells can reexpress their E-cadherin as soon as they reach the far sites. Re-expression of E-cadherin by cancer cells can be found in all metastasis of ductal carcinoma and their expression level can be the as high as or even higher than the expression in the primary tumors. ${ }^{10}$ By learning E-cadherin expression in metastasis of breast carcinoma in lymph nodes, Bukholm et.al (cited by Kowalczyk et al. 1994) showed that in nineteen out of twenty metastasis in lymph nodes strongly re-express the E-cadherin. ${ }^{10}$

Graff et al. (cited by Madhavan, et al. 2001) found that down regulated E-cadherin in early stage of metastasis will 
re-express in its metastasis deposit. ${ }^{12}$ E-cadherin odds ratio analysis in our study shows that down regulation can function as metastasis predictive marker in breast carcinoma. This fact shows the important role of E-cadherin in predicting the occurrence of metastasis in cases with negative lymph nodes, but eventually have micro metastasis that are undetected/ undiagnosed histologically so that doctors may under diagnose their patients. ${ }^{10,12}$

ROC curve to evaluate the relationship between markers, such as E-cadherin or $\mathrm{NM} 23 \mathrm{H} 1$ and metastasis shows significant relationship of both markers and metastasis. The two ROC curves show that as metastasis markers, E-cadherin expression is specific, and NM23H1 expression is both sensitive and specific. Comparison of the curve of E-cadherin and NM23H1 expressions in metastasis prediction shows an area of difference of 0.048 . Therefore, the ability of E-cadherin and NM23H1 to predict metastasis does not differ significantly. This fact agrees with molecular biology theory stating that $\mathrm{NM} 23 \mathrm{H} 1$ is a metastasis suppressor, while E-cadherin is a tumor and/or invasion suppressor, so that either individually or collectively the two markers are significant in preventing tumor growth, invasion, and metastasis.

The chance of both positive E-cadherin and NM23H1 expressions to prevent invasion and metastasis is twenty-nine times the chance of negative E-cadherin and NM23H1 expressions. Further, the chance of positive E-cadherin and negative NM23H1 expressions to prevent metastasis and invasion is nine times the chance of both negative E-cadherin and NM23H1 expression. Therefore, it can be concluded that E-cadherin and NM23H1 expressions can be used as invasion and metastasis markers, both individually and collectively.

The result of gradation analysis, ROC curves, and combined tables of E-cadherin and NM23H1 support the significant association between either E-cadherin or NM23H1 and both markers with metastasis, which is specific and sensitive. Taking all the analyses into account, it can be concluded that E-cadherin and NM23H1 are good invasion and metastasis markers.

A priori and a posteriori probability comparison shows the percentage of metastasis prediction before and after immunohistochemistry staining. In this study, there is an increase of E-cadherin metastasis prevention from a priori of $50.5 \%$ to a posteriori of $99.9 \%$, which shows an increase of $49.4 \%$. The significant increase in a posteriori probabilities in this study shows the effectiveness of immunohistochemistry staining to predict the occurrence of metastasis. Our results agree with the application of immunohistochemistry markers by Veneis (1997) in his research on cancer. The aim is to provide a gold standard of immunohistochemical staining to predict the occurrence of metastasis for clinical use. ${ }^{9}$
The most valuable result of this study is that the chance of positive E-cadherin expression to prevent metastasis and invasion is 13.6 times the chance of negative E-cadherin expression. The chance of weak positive NM23H1 expression to prevent metastasis is eleven times the chance of negative NM23H1 expression. Further, gradation analysis of combined expressions of weak positive E-cadherin and NM23H1 shows a significant increase in Odds ratio that is sensitive and specific for metastasis.

Impairments in the expression of certain genes may be due to epigenetic disorder or mutation. Epigenetic disorder occurring in E-cadherin is only about 25$30 \%$ and the rest is due to mutation, while most disorders occurring in $\mathrm{NM} 23 \mathrm{H} 1$ are epigenetic. Epigenetic disorders are expected to response to demethylation therapy, which recently widely used. ${ }^{18}$ The hypermethylated genes are expected to become normal after demethylation therapy. Further studies using RT-PCR to distinguish cases with mutation from epigenetic/hypermethylation are urgent, so that doctors can give optimum treatments to their patients.

In conclusion, E-cadherin and NM23HI expressions can be used as invasion and metastasis markers, but cannot be used as markers for the degree of histological malignancy in invasive ductal carcinoma.

\section{REFERENCES}

1. Department of Health and Human Services, Centers for disease Control and Prevention. National Program of cancer statistics (USCS). 2007 Top Ten Cancer's [Internet]. [Cited 2011 April 1]. Available from: http://www.cdc.gov/uscs.

2. Tjindarbumi D, Mangunkusumo R. Cancer in Indonesia, present and future. J Clin Oncol. 2002;32:17-21.

3. RamliM.Kankerpayudara, deteksi dinidan penatalaksanaan masa kini. Seminar sehari deteksi dini kanker. Muktamar V/PIT XII:Jogjakarta;2000. [Indonesian].

4. Leong AS. Short course of molecular immunohistology. The sixth annual scientific meeting Asia-Pacific society for molecular immunohistology (APSM). The Sunway Medical Center of Malaysia; 2011.

5. Sastroasmoro $\mathrm{S}$, Ismael $\mathrm{S}$. Dasar-dasar metodologi penelitian klinis. 2nd edition. Jakarta ; Sagung Seto: 2002. [Indonesian].

6. Departemen Ilmu Kedokteran Komunitas FKUI. Kumpulan bahan kuliah epidemiologi biostatistik. Jakarta: Departemen Ilmu Kedokteran Komunitas; 2004. [Indonesian].

7. Nichols GE, Frierson HF, Boyd JC, Hanigan MH. Automated immunohistochemical assay for estrogen status in breast cancer using monoclonal antibody CC4-5 on the Ventana ES. Am J Clin Pathol. 1996;106:332-8.

8. MedCalc version 9.6.4.0. for Windows. Statistics for biomedical research software manual. Mariakerke: Microsoft; 2003.

9. Vineis P. Sources of variation in biomarkers. In:Toniolo P, Boffetta P, Shuker DEG, Rothman N, Hulka B, Pearce N, editors. Application of biomarkers in cancer epidemiology. Lyon: IARC Scientific Publications; 1997. p. 59-71. 
10. Kowalczyk AP, Palka HL, Luu HH, Nilles LA, Anderson JE, Wheelock MJ, et al. Posttranslational regulation of plakoglobin expression. Influence of the desmosomal cadherins on plakoglobin metabolic stability. J Biol Chem. 1994;269:31214-23.

11. Mastracci TL, Tjan S, Bane AL, Malley FPO, Andrulis IL. E-cadherin alterations in atypical lobular hyperplasia and lobular carcinoma in situ of the breast. Mod Path. 2005;18:741-51.

12. Madhavan M, Srinivas P, Abraham E, Ahmed I, Mathew A, Vijayalekshmi NR, et al. Cadherins as predictive markers of nodal metastasis in breast cancer. Mod Pathol. 2001;14:423-7.

13. Berx G, Roy V. The E-cadherin/Catenin complex: an important gatekeeper in breast cancer tumorigenesis and malignant progression. Breast Cancer Res. 2001;3:289-93.
14. Knudsen KA, Wheelock M J. Cadherin and the mammary gland. J Cell Biol. 2005;95:488-96.

15. Dickson RB, Lippman ME. Molecular basis of breast cancer. In: Mendelsohn J, Howley PM, Israel MA, Liotta LA, editors. The molecular basis of cancer. 2 ed. Philadelphia; WB Saunders; 2001. p. 326-9.

16. Steeg PS. Metastasis suppressors alter the signal transduction of cancer cells. Nature Reviews Cancer. 2003; 3: 55-63.

17. Steeg PS, Palmieri D, Ouatas T, Salerno M. Histidine kinases and Histidine phosphorylated proteins in mammalian cell biology, signal transduction and cancer. Cancer Letters. 2003; 1-12. [cited 2006 Dec 15]. Available from: http:// www.sciencedirect.com.

18. Roymans D, Willems R, Van Blockstaele DR, Slegers H. Nucleoside diphosphate kinase (NDPK/NM23) and the waltz with multiple partners: possible consequences in tumor metastasis. Clinical \& experimental metastasis. 2002;9:465-76. 